\title{
The Role of the Forest in German Literature: From the Medieval Forest to the Grünes Band
}

\author{
Albrecht Classen \\ University of Arizona, Tucson, USA
}

\begin{abstract}
This paper demonstrates how much the forest was used by medieval writers as a symbolic space where critical events take place deeply affecting their protagonists. The forest motif can be found in the works of St. Augustine as well as in Dante's Divina Commedia (ca. 1308-1321), and then in a plethora of other texts. Here the author examines more closely the symbolic meaning of the forest as a mysterious, dangerous, yet also spiritual location in Wolfram von Eschenbach's Titurel (ca. 1220) and then in two 15th-century prose novels: Thüring von Ringoltingen's Melusine (1456) and the anonymous Fortunatus (1509). Each time we recognize how much the poets placed their central figures one in the forest where their life takes a major turn. Recognizing this intriguing function of the forest as a metaphor and symbol, we can employ the modern interest in and fascination with the forest as a refuge from the destruction of the natural environment through modern civilization as segue to attract students to the study of medieval literature once again.
\end{abstract}

Keywords: forest as symbol, St. Augustine, Dante Alighieri, Wolfram von Eschenbach, Thüring von Ringoltingen, Fortunatus, relevance of medieval literature

\section{Introduction}

In his Confessiones (1960), St. Augustine reflects at one point about the difference between the writings of the ancient philosophers and the passionate, emotional quest for the soul's salvation in the Christian world. In that context he resorts to a powerful metaphor that serves us extraordinarily well to outline the theoretical and practical perspectives that the author wants to pursue here. Augustine (1960) emphasizes:

It is one thing to behold from a wooded mountain peak the land of peace, but to find no way to it, and to strive in vain towards it by unpassable ways, ambushed and beset by fugitives and deserters, under their leader, the lion and the dragon. It is a different thing to keep to the way that leads to that land, guarded by the protection of the heavenly commander, where no deserters from the heavenly army lie in wait like bandits. (p. 180)

For him, as for countless other writers throughout the Middle Ages and far beyond, if not until today, the experience of being lost in the woods constitutes an archetypal condition. The forest is a space where human conditions and laws no longer apply; hence both wild animals and robbers have fair play and can do whatever they please. The forest is similarly the prime territory in fairy tales where wild things appear and threaten the protagonists. Every culture and society has viewed the forest differently, and we can study a certain cultural 
period very well through the lens of the forest, but each time we will recognize how much the forest served as a symbol and a metaphor. Herein the author perceives extraordinarily productive strategies to make modern students aware about the importance and intrigue of the theme of the forest in medieval literature (Fischer, 2011). ${ }^{1}$

\section{The Forest in Medieval Literature: A Brief Survey}

Dante Alighieri (ca. 1265-1321) embraced a very similar image in the introduction to his Divina Commedia (1974), positioning his protagonist in the midst of the woods, not knowing where to turn any longer:

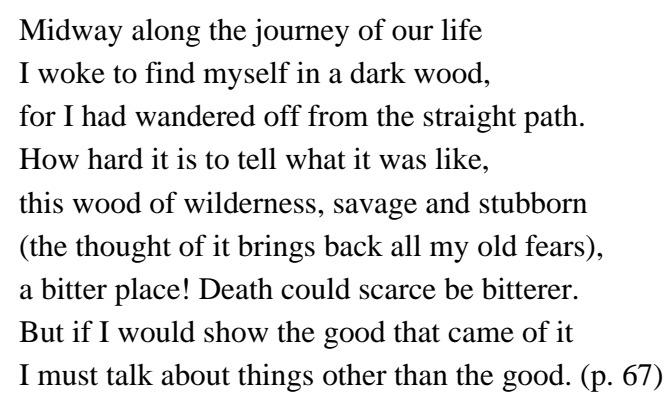

Indeed, the forest has always served as an intriguing site for epistemological investigations, since human culture extends only to the edge of the last meadow or pasture, where the wilderness begins, but where a new world also awaits the visitor, the hermit, the monk, or anyone looking for freedom from social constraints (Semmler, 1991, pp. 9-15). ${ }^{2}$ In Walther von der Vogelweide's famous poem “Under der linden” (2013), the two lovers meet at a meadow, under a linden tree, hence away from human society, but not yet in the wild forest; instead, just at its edge.

Courtly literature is deeply determined by images of the forest where beasts live and where only the most daring individuals, if not the mad, enter (Saunders, 1993). The courtly protagonist proves his prowess especially in the forest where he encounters dangerous opponents and fundamental challenges to his own existence (Erec, Yvain, Gawain, Lancelot, Partonopier, etc.). Sir Gawain, for instance, in the Middle English alliterative romance Sir Gawain and the Green Knight (the late 14th century), has to make his way through the frozen landscape of Northern Wales and fight at many occasions against dragons and wolves before he finally reaches, just in time for the Christmas season, the castle of Hautdesert, where the next stage of his testing begins (vv. 691-762). The poet leaves no doubt as to the profound dangers which Gawain has to face, especially since he even seems to be threatened in his life because of the inhospitality of the wintry forest:

\footnotetext{
By a mount in the morning the good man then rides

Into a forest full deep, fantastic and wild,

High hills on each side, and heavy woods beneath

With bare oaks, very huge, a hundred together.

The hazel and the hawthorn were thickly ensnarled,
}

\footnotetext{
${ }^{1}$ Fischer indicates, for instance, how much the forest was a mythical space in the Middle Ages, and then became a location of refuge from society for the Romantics. At the same time, the forest matters greatly in the entire world of the fairy tale.

2 See especially Semmler's introductory comments on the variety of functions which the forest could assume in the Middle Ages, pp. 9-15; for the relevance of the forest in early modern English literature, see Theis (2009), A remarkable paean on the forest as a refuge for all people after destructive wars or environmental disasters, for instance, was written by Giono (1954/1985), The man who planted trees.
} 
with rough, ragged moss arrayed everywhere, With many birds, not blitheful, upon bare twigs, That piteously piped there in pain from the cold. (Sir Gawain, vv. 740-747)

However, Gawain survives, and ultimately triumphs, even though the Green Knight subsequently severely tests him and would have almost defeated him with the help of his wife who works hard to seduce this worthy representative of the round table. Details do not need to be pursued here at length, and suffice it to confirm that the Gawain poet powerfully employed the imagery of the forest for his epistemological purposes since the protagonist can only find his goal and master the task posed by the Green Knight once he has made his way through the forest to the castle, and from there to the green chapel (Brewer \& Gibson, 1997; Elliott, 1979). Significantly, each one of the three animals which the Green Knight/Bercilak de Hautdesert hunts during the three days while Gawain stays with him and rests in bed well into the late morning, specifically symbolizes one of the latter's knightly skills and character. While Bercilak races along the edge of the forest ("lynde-wode 3 eues”, v. 1178), his wife entraps Gawain by sitting down on his bedside (v. 1193), and we are left guessing who of the two men is at a more dangerous spot, who is the true hunter, and who is the spoor. Although there are many references to social-courtly settings throughout the text (castle, chapel), the forest itself determines Gawain's course toward his destiny and the time of his ultimate test regarding his courage and honor. While the Green Knight had first visited the castle of King Arthur, he awaited Sir Gawain at the green chapel, in a forlorn part of the woods, in a dale far away from all human civilization (vv. 2160-2198).

There are countless other examples of forest scenes in medieval literature, which contain a multitude of ponderous signifiers in which individuals either feel completely lost, or recognize that they have entered a utopian or dystopian space. In light of contemporary interest in the forest and wilderness as the last remaining refuge for nature in face of ever expanding modern civilization, the question that the author wants to raise here is how the discussion of the forest might facilitate a reinvigoration of student interests in medieval literature? Ecocriticism is not just a catch-word coined by postmodernist theoreticians or green-oriented environmentalists; instead, it is the result of deeply-grounded concerns by people today about the survival of our world as we know it, especially of nature (Scarborough, 2013; Classen, 2012; Rudd, 2007; Aberth, 2012). ${ }^{3}$ At the same time, as we will observe, the discussion of the forest as a magical space, as a maze wherein the weak and ignoramus will be lost, while the strong and wise will succeed, carries timeless values (Wilson, 2012; Lekan, \& Zeller, 2005). ${ }^{4}$ The forest represents in many different ways cultural identity because of its enormous symbolic value throughout times, either in a hospitable or a hostile fashion.

\section{Ecocriticism Past and Present, and the Spatial Turn}

Ecocritical awareness is not simply the result of postmodern reactions to the destruction of our natural world by economic-capitalistic interests and hence industrial and other pollution. Instead, as the author will illustrate in this paper, concerns about the natural environment can be traced already in much earlier literature. If we recognize some of the universal issues at stake also in medieval texts, we will be in a much better position to

\footnotetext{
${ }^{3}$ Medievalists have recently turned to ecocriticism, which promises to build highly productive bridges to modernism, revealing universal concerns beyond all historical dividers.

${ }^{4}$ For modern perspectives, see Wilson (2012) and Lekan and Zeller (2005).
} 
justify our discipline, medieval studies. This goal must be pursued not only for cultural-historical reasons, but also because the voices contained in those literary documents prove to be partners in a larger discourse that affects us as much today as in the past. The ecocritical concern is not only directed toward the natural environment, but it also and essentially considers the healthy or unhealthy relationship between mankind and nature (Hiltner, 2013). This approach must be pursued both with a perspective toward the modern conditions and in light of the situation in the past, as reflected, for instance, by medieval literature.

Space carries meaning, and the natural environment as well, as we know so well since the beginning of the “spatial turn” (Lefebvre, 1974/1991; Kipfer, Goonewardena, Schmid, \& Milgrom, 2008). Our constantly growing concern with the forest today connects us immediately with the approaches toward the forest in the Middle Ages since we can recognize in that natural space a world where the self is deeply challenged and where human society finds its limits. Entering the forest, hence, represents, in a way, one of the possible pathways toward utopia (Thomasset \& James-Raoul, 2005; Hartmann, 2010; Classen, 2000, pp. 133-156), ${ }^{5}$ the intellectual and spiritual exploration of a new space, far away from human society. Or, just on the opposite, losing one's way in the forest could also be, as Dante's example illustrates, the experience of a dystopia or of an existential crisis. Furthermore, there is also a number of literary cases where a young protagonist grows up in the forest, far away from courtly society, and has to learn, after his departure, how to adapt to the world outside and how to acquire the necessary skills required from a knight and a chivalrous person in the adult environment at court, such as Chrétien de Troyes's Perceval or Wolfram von Eschenbach's Parzival in their respective eponymous romances (Classen, 2012b, pp. 51-55). As Perez (2012) notes:

Located on the margins of society, the forest is omnipresent not only in the imagination of the poets, but also in the lives of all medieval society. It surrounds the rural space, marking the limits of the cultivated lands, and often constitutes a natural border, the frontier between two adjacent territories. (p. 439)

\section{Medieval Literature Today: The Meaning of the Forest}

In order to come to terms with the issue at stake here, the author will discuss an early 13th-century text where the forest space matters greatly for the development of the narrative and the protagonists' lives, and then two 15th-century prose novel to demonstrate not only the great importance of the forest as a motif and backdrop in each text. The critical question here pertains to how the discussion of the forest in each literary example can emerge as a crucial stepping stone to attract new readers to the medieval world. After all, our modern society is deeply determined by the Middle Ages, and the connection between both cultures in philosophical, religious, political, economic, and artistic terms are extensive, even if not so obvious at first sight for the outsider (Fuhrmann, 1996; Zink, 1996/1998). ${ }^{6}$

Basically, the author no longer need to confirm how much the forest itself mattered for the narrative development of so many medieval (and also modern) texts. We only need to think of Marie de France's "Bisclavret” (ca. 1190), for instance, where the unfortunate husband is forced to live in the forest as a werewolf until, under unique and difficult circumstances, he receives, upon the advice of a wise councilor, a new set of

\footnotetext{
${ }^{5}$ For a wide range of discussions about utopias already in the Middle Ages, see Thomasset and James-Raoul (2005); see also the succinct article by Hartmann (2010) and Classen (2000).

6 There are many researches on this topic by now, and scholars continue to discover ever new connections or sources of influence. See, for instance, Fuhrmann (1996).
} 
clothing from the king and can thus shift back to his human shape, but not before he has bitten off the nose of his wife as a punishment for her evil deed against him, banning him to a life in the wilderness (Marie de France, 2010, 2011; Sharon \& McCracken, 2012). ${ }^{7}$ Or we could explore the "chante fable” Aucassin et Nicolette (ca. 1230-1250) where the female protagonist hides in a forest until her lover, having fled from his home country, can finally discover her and then move on together with her, disregarding previous social pressures exerted against them (Dufournet, 1984; Gilbert, 1997; Angeli, 2006). ${ }^{8}$

The burning question in medieval studies centers nowadays very much on how we can motivate our students to pay attention to literary texts from the premodern era, how to make them relevant again, or how to preserve their traditional role within the larger canon of Western literature (Classen, 2012a). The focus on the motif of the forest promises to be one of many useful strategies, especially because it has long been recognized as a critical epistemological tool of great heuristic value (Eco, 1994; Adam, 1988). ${ }^{9}$ We can traverse such a symbolic forest in order to make our way to another goal beyond it, or we can explore the forest in order to understand its infrastructure or the various types of habitats present there. Getting lost in the forest, as happens so often in fairy tales (such as in “Hänsel and Gretel” or "Little Red Riding Hood") easily and commonly symbolizes the basic human experience of not knowing where to turn in one's life, as Dante formulated already so powerfully (see above).

But we also find lovers camping out in the midst of the forest, not knowing about the spiritual meaning of the natural setting, who then experience a dramatic upheaval in their lives because of their ignorance. The sylvian environment can be the place of a utopia, or, as the outcome of this story, to be discussed below, implies, a dystopia. These enigmatic clues about this so-far unmentioned text might serve to demonstrate how much medieval literature can actually address modern concerns in a timeless fashion (Chazelle, Doubleday, Felice, \& Remensnyder, 2012).

After all, there is no doubt that the present generation is deeply involved in the preservation of the forest as the green lungs of our world. A great example for this movement today proves to be the establishment of national parks in the middle of Germany, in the form of the so-called "Grünes Band” (Green Band), preserving the strip of land that had been used by the East German regime for their border to the West (Cornelius, 2010; Frobel, Geidezis, \& Kreutz, 2011). ${ }^{10}$ We can also refer to the massive movement in the 1980 s to preserve the German forests that were threatened by environmental pollution. Both mythology and ideology have always played with the iconography of the forest, at least in German culture, insofar as every period since the Middle Ages and earlier has engaged with the forest as a symbol, value, and metaphor. Little wonder, then, that focusing on the forest in medieval literature also promises to yield major results because the critical treatment of people's lives when they spend time in the forest for a variety of reasons potentially illustrates existential concerns (Lehmann, 1998; Zechner, 2006). The forest is not quite like a labyrinth, but it is a kind of maze which certainly challenges anyone

\footnotetext{
${ }_{8}^{7}$ He also provides, in part, a reprint of the original texts. See Whalen (2011), Kinoshita and McCracken (2012).

${ }^{8}$ Research on this chantefable is not very rich; but see, for instance, Gilbert (1997), The role of the forest, however, has mostly escaped scholars' attention. Somewhat useful proves to be Angeli (2006).

9 The term "poetic forest" was commonly used in Baroque and Enlightenment literature.

10 This is only one of a whole series of volumes, all of them covering the entire stretch of land from the Baltic See down to northern Bavaria that once used to be the East-German Border. See also Frobel, Geidezis, and Kreutz (2011). The literature on this topic has become legion by now.
} 
who does not know its topography and infrastructure well enough and cannot map the thicket and underbrush, or who gets lost in the disarray of seemingly endless trees. As Penelope Doob (1990) informs us:

For Prudentius, life is a maze or, rather, a pair of mazes: in one, God is guide and reward; in the other, confusion and death abound. Pagans like Plato and Aristotle had no choice but to whirl along the downward winding of the demonic labyrinth, but Christians have supernatural assistance to find the single path to heaven. (p. 78)

As Gregory Thaumaturgus (ca. 213-270) commented:

But after all, there is neither any labyrinth so inextricable and intricate, nor any forest so dense and devious, nor any plain or swamp so difficult for those to get out of who have once got within it, as is discussion, at least, as one may meet with it in the case of certain of these philosophers. (as cited in Doob, 1990, p. 78)

So, there is hope, especially if one relies on discourse, logic, and intellect, not to mention trust in God. Nevertheless, the forest continued to plague medieval writers as an epistemological, if not existential, challenge, as Wolfram von Eschenbach demonstrates in his fragmentary Titurel, above all, the first key witness in our examination (Wolfram von Eschenbach, 1988). ${ }^{11}$

\section{Wolfram von Eschenbach's Titurel: The Message of the Forest}

Rarely was there any other text composed by a medieval writer where so much pre-understanding is necessary to make sense out of it. Wolfram simply picked up a loose narrative thread from his grail romance, Parzival (ca. 1205), and developed it a little further in his Titurel, but he obviously did not care, or could not, complete it before his death (ca. 1220). Recent scholarship has discovered its literary brilliance and has begun to analyze this curious piece much more carefully than ever before (Classen, 1990; Sager, 2006; Tax, 2011). While the first fragment is deeply determined by the theme of death and the disappearance of the entire Grail family, at the end new hope emerges because the families agree that Sigune, the last heir of the Grail, and the noble Schionatulander can love each other. The second fragment fast-forwards to a moment when the two are already spending time together in a sylvian idyll, having set up camp in a lightening near a brook in which the young man is trying to catch fish. At that moment a dog's barking can be heard, and Schionatulander is lucky enough, when he runs toward the dog, to catch it and to bring it to his beloved, Sigune. Ominously, however, the narrator warns us from the beginning that the arrival of the dog, meaningfully named "Gardeviaz" (keep on the trail), anticipates sorrow: "It brought him future sadness” (stanza 134, line 3). Although the dog comes with a highly valuable leash, finely embossed with jewels, which altogether create letters, which in turn form words, and hence a message, this animal is on the loose, chasing after a bleeding prey, and races “through the thicket” (stanza 137, line 1).

Sigune immediately demonstrates strong interest in this animal, or rather, in the text, since she senses that it carries a special message indirectly intended for her. As is always the case in medieval literature, everything has some meaning here and awaits its decoding by the one who is intelligent enough to do so (Curley, 1979; Obermaier, 2009). ${ }^{12}$ Both the dog and the inscription on the leash inform the young woman about tragic lovers

\footnotetext{
${ }^{11}$ For a historical-critical edition, see Wolfram von Eschenbach (2003); here the author will quote from the English trans.: von Eschenbach (1988).

12 See the famous collection of allegorizing narratives about animals highly popular throughout the entire Middle Ages, Physiologus (1979). It dates back to the second or the third century, but was first translated into Latin in ca. 700 (http://en.wikipedia.org/wiki/Physiologus). See also the contributions to Sabine (2009).
} 
before her who had not been able to "stay on the right trail” (stanza 144, line 3) and had disregarded the warning written on the leash. As stanza 148 relates, for instance:

He met his end too in service under arms for her love. If it were not a violation of my sense of propriety, I should still be cursing the hand that caused his death in a joust. Florie died in that joust too, although she never came close to the point of a lance.

We do not need to investigate here what other sorrowful love stories Sigune reads on the leash; it only matters for us that she cannot control her desire to learn about the outcome of the text, which is hidden from her view, however, because of a knot with which the leash is attached to the tent pole. As soon as Sigune has loosened that knot in order to keep reading, the dog feels the slackening of the leash and runs off, quickly disappeared in the forest, barking loudly while tracing the spoor of some (or the same) animal as before. Schionatulander, who had been fishing in the brook, races after the dog, but he is not fortunate enough to achieve his goal this time because "[t]he trackless forest had let the dog get so far away from him that he could locate neither game nor dog, and the wind was playing tricks on his hearing too" (stanza 160, lines 3-4).

When the two lovers come together again, they both bewail each other's wounds. Sigune had tried to hold on to the leash and thus to retain both the dog and the text, but the gems on the silk band had only run through her palms, making them bleed (stanza 162). Schionatulander, on the other hand, suffers from bloody wounds on his feet and legs resulting from his rushing through the brambles and running over sharp tree stumps. Both observe each other's wounds and lament them (stanza 163), but Sigune is not willing to let things stand as they are at that moment. Instead, she now insists that her lover accept as his challenge the pursuit of the dog: "if you will still be seeking to serve to gain my love, you must first obtain for me the leash with which Gardeviaz was tied in here” (stanza 166, line 4).

Unfortunately, and tragically, we know already the outcome of the future events from Wolfram's Parzival because there we were told that Schionatulander encountered a mighty knight, Orilus, who had caught the dog and refused to turn it over to the young man. In the ensuing joust, Schionatulander died, and for the rest of the romance we only hear of the mourning Sigune who finally passes away, filled with enormous grief. She holds her lover's corpse in her lap, thus imitating the famous pietà figure, but there is no hope for her, not even in religious terms. In Titurel (ca. 1220), Wolfram outlines briefly the cause for this tragedy, blaming Sigune for her inability to read carefully enough and to understand the warning "written” on the leash. But there is more to the story, since the wounds caused by the leash and the brambles are directly related to the forest and the special situation the two lovers are in, briefly spending time in the utopian space of the forest clearing. However, as the narrator indicated already in the first fragment, and as the outcome of the second one, where the protagonists operate in the midst of the forest, confirms, love as a wild force, as the untamed other, overpowers these two young people and throws them into the thralls of death and devastation. Everything here is told from the perspective of the bitter outcome, and death seems to rule, both within the entire Grail family, threatened by extinction, as the genealogical outline in the introductory section emphasizes, and at its margin, since love can no longer be controlled, escaping the grasp of those who should live it out as role models of their society.

Haug (1980/1989) recognized in Wolfram's Titurel that an image of a courtly world where nothing operates any longer as it should, neither knighthood (resulting in deaths) nor chivalry with its erotic sublimation (death of 
the lovers) (p. 549). The lovers no longer find the necessary support structure among their family members in this unique situation, even though they are neither opposed to their love, nor among courtly society at large and thus easily become victims of the forest, the metaphorical alterity in their own existence. It is not enough, as Haug (1980/1989) has claimed, to recognize in Titurel simply one of several attempts by the poet to probe the validity of the Arthurian concept altogether within its literary framework and hence the strength of the ideal of literary fictionality (p. 553). ${ }^{13}$ Instead, as various important scenes in Wolfram's Parzival confirm, the forest serves exceedingly well as the essential backdrop for epistemological explorations.

Parzival's mother Herzeloyde had withdrawn into the forest solitude of Soltane to protect her son from the dangers resulting from all knighthood, since her husband Gahmuret had died in military service (Wolfram von Eschenbach, 1998; Dallapiazza, 2009). But hiding away from society and keeping the child in artificial isolation, that is, in the wild uncivilized forest, cannot prevent his growing up and his urge to learn about the world, and hence about himself. Consequently, Parzival abandons the forest in order to find King Arthur and the Round Table, not realizing, however, that his mothers dies the moment he departs from her, having been a victim of her own self-illusion about the forest as a safe haven from outside dangers.

In Titurel, the forest at first seems to be idyllic, with the camp set up in a free and unperturbed space, yet surrounded by thorny bushes and brambles. This protective location does not prevent the outside world to reach that refuge both in the form of the dog and of the mysterious leash. Neither one stays with Sigune for long, and once Gardeviaz has escaped again, in hot pursuit of a game, following his own wild instinct, bloody traces become visible both on Sigune's and Schionatulander's bodies. While the script on the leash was made of valuable gems, the text on their skin is written with blood, almost as a divine message. Tragically, however, they cannot read those words and do not understand that chasing after the dog would only lead the prince to his own death and to the princess's life-long mourning. Blood proves to be the most precious "ink", writing itself on the human "parchment", which clearly signals that the entire episode in the forest idyll would have to be read also in religious and epistemological terms (Walker Bynum, 2007; Bildhauer, 2006, pp. 65-66; Gadebusch Bondio, 2005). ${ }^{14}$

Even though the two lovers at first seem to spend their time in a secure haven, in the calm and delightful clearing, which is not even fully outlined by the narrator, life-threatening dangers surround them, as signaled by the blood-thirsty dog: "hot on the blood-red spoor of a wounded animal” (stanza 132, line 2). The dog's barking resounds throughout the forest, disturbing the tranquility and peace, announcing, as the narrator alerts us immediately, to imminent death: "He will sell his joy and in doing so receive lasting sadness in return" (stanza 134, lines 2-3).

Marie de France had created a quite similar scene in her lai "Guigemar" where the protagonist—a young man with no feeling of love and no interest in the other gender-kills a doe and yet is badly wounded at the

\footnotetext{
${ }^{13}$ He follows in this regard pretty much the suggestion by Wyss (1974), although such a position is predicated too theoretically on the idea that poets ultimately only reflect on their own creative activity.

${ }^{14}$ She discusses historical-religious aspects in the late Middle Ages, but her theoretical underpinnings can certainly be used for our own investigation. See also Bildhauer (2006) and Gadebusch Bondio (2005). None of these scholars have paid attention to Wolfram's Titurel, and none has investigated what the bloody script in general would signify.
} 
same time because his arrow bounces back and penetrates his thigh. While Gardeviaz's leash carries the relevant message, though its critical parts are hidden and then lost because the dog escapes, here the doe informs the hunter about his future:

May you never have a cure! Neither from herbs nor roots, nor by potions nor by a physician will you ever be cured of the wound you have in your thigh, until she cures you who, for love of you, will suffer great pain and great sadness such that no woman has ever suffered; and you will suffer the same for her, and all those who love, have loved, or will love in the future will marvel at this. (Marie de France, 2010, p. 5) ${ }^{15}$

Wolfram's words sound surprisingly similar: "He had to experience unflinchingly grief lined with toil and great striving for combat ever more. The hound's leash was indeed for him the source of joyless times" (stanza 138, lines 2-4). However, the difference between both stories also could not be greater because once Guigemar has left the forest, he encounters a magical ship that automatically transports him to his future beloved. Schionatulander, by contrast, at first cannot penetrate the forest when he is chasing after the dog because he has no shoes on and is bare-legged, and later, once he has succeeded in embarking on his quest, as we learn from the account in Parzival, he runs into a deadly joust with Orilus, thereby making the tragic prophecy come true which was indirectly related in the text on the dog leash, as we can surmise.

As should have become clear by now, Wolfram intriguingly operates with the motif of the forest as a symbolic stage where the individuals of his account are tested according to their intellectual and spiritual abilities. In the case of Parzival we can observe a number of similarities, but ultimately the protagonist always succeeds to compensate his shortcomings and failures, being helped by others and being led by his pure love for his wife and his dream of liberating the Grail kingdom of its curse (Bumke, 2001). ${ }^{16}$ This is no longer the case in Titurel, where the forest basically surrounds and engulfs the lovers, bringing death and sorrow upon them because they are no longer able to read the various signs and are caught in a world where the traditional values and norms are no longer valid, refusing to guide them through an increasingly alienated world, dominated by the forest, a symbolic space where this process of losing one's orientation takes place.

\section{The Forest in Thüring von Ringoltingen's Melusine}

From here the author wants to jump to the late Middle Ages and examine two other examples where the interaction between the protagonist and the forest reveals how much natural spaces, especially a territory occupied by a dense wood, reflect on the character's problems and issues. In the highly popular Melusine by the Swiss writer Thüring von Ringoltingen (1456, many printed versions since 1474) (Gotzkowsky, 1991, pp. 105-125), ${ }^{17}$ we encounter a narrative plot that originates in the forest and concludes there as well because tragedy strikes right from the start and is overcome only partially, before another catastrophe occurs. In essence, the poet discusses the married life of the snake-woman Melusine with Reymund, which at first develops well and impresses everyone

\footnotetext{
${ }^{15}$ Even though Marie does not identify the forest specifically as the "agent” of these events, it is the sylvian space where love is tested and lovers experience the greatest challenge in their lives.

${ }^{16}$ Bumke (2001) discusses the wider philosophical-historical context at least of the account in Wolfram's Parzival. Our analysis of the Titurel unfortunately takes us to the very bitter conclusion of the forest as the existential and symbolic maze where some are blessed to find their way out at the end, while others have to perish.

17 See also the latest update on the manuscripts (Rerieved from: http://www.handschriftencensus.de/werke/1873 (last accessed on November 20, 2013)).
} 
because of its harmonious and close collaboration, until Reymund's brother implants fear and envy in the protagonist's heart since he suspects his wife of adultery. In order to learn the truth about her, Reymund breaks the taboo imposed upon him by Melusine not to inquire about his wife's whereabout on those special Saturdays (Classen, 1995/1999, pp. 141-162).

Even though the marriage had resulted in numerous male heirs, who grow up and later establish their own kingships and dynasties, Reymund is finally convinced by his own brother, curiously called "graf vom vorst" (Müller, 1990, p. 96; Count of the Forest), to investigate, after all, despite his original vow and promise never to transgress his pledge to observe the taboo. Instead of trusting his wife and respecting her privacy, as a premise of their marriage contract, Reymund cannot help himself and must find out what his wife is doing behind the closed door on Saturdays, whether she is, for instance, having an affair with another man. Tragically, Reymund realizes, too late, that he has destroyed the nimbus which his wife had created around herself for her self-protection and her strategy to become reintegrated into human society after having been condemned by her mother Persina to live as a fairy for the rest of eternity as a punishment for her and her two sisters' violent transgression against their father, who in turn had committed a transgression against his wife.

At first, however, since Reymund does not divulge Melusine's strange nature to the public, she quietly forgives his breach and allows him to continue living the happy life of a content husband with her. But as soon as he has subsequently lambasted his wife in public for being half a snake and only half a human being (Müller, 1990, pp. 114-115), nothing can protect her any longer and she is forced to leave her family and all of human society, which devastates Reymund as her husband, while the history of their sons continues without any major disruption (Müller, 1990; Drittenbass, \& Schnyder, 2010; Classen, 1995, pp. 141-162). ${ }^{18}$

Why would the forest matter, however, in this mythical context? First of all, Reymund runs into an existential crisis at the beginning when he accidentally kills his cousin during a hunt in the forest. Completely disturbed and desperate, he roams through the forest until he suddenly comes across a group of three women, one of whom, Melusine, approaches him and makes the ominous offer to help him out of his terrible situation and to establish both a marriage and a dynasty with her. Once he has agreed to her contract, she instructs him how to carve out a huge estate of his own in the midst of the forest by means of a dear hide cut into very thin strings by which they demarcate the new territory, which comprises both forests and valleys, farms and meadows (Müller, 1990, pp. 30-33). Melusine thus is entitled to reenter into human society and to develop her own territory, as Reymund's wife, although in reality she is the leading figure in their marriage. Ultimately, however, as we have seen already, all her efforts to build a new world within the virginal land of the forest where she can reside undisturbed by external forces fail because even her own husband begins to distrust her and finally betrays her true nature to the world because his son Geffroy had murdered his younger brother Freymund.

The poet, mostly drawing from a French source (Couldrette, ca. 1400), ${ }^{19}$ does not specifically embrace the

\footnotetext{
18 The text is quoted from Müller (1990); for recent scholarly investigations on this text, see the contributions to Drittenbass, and Schnyder (2010). However, the specific analytic approach pursued here has not yet been dealt with in previous research. For an overview of older research, along with critical discussions, see Classen (1995).

19 The original story actually dates back to mythical accounts commonly known in medieval Europe, all of them predicated on the theme of a mysterious woman whose true nature as a dragon or snake is later found out when her human husband spies on her. Despite numerous differences, every author places the encounter between the woman and the future husband in the forest, a place far away from the court and, especially, the Church. See the commentary by Müller (1990, pp. 1020-1031).
} 
forest as the staging ground for his two protagonists. Nevertheless, the decisive elements of the narrative plot take place in the forest which thus becomes the catalyst for human destiny. Reymund kills his cousin on the hunt; he encounters the fairy-figure Melusine in the forest; upon her urging and advice he establishes a dynastic territory in the forest, but then, at the end, his own brother, explicitly associated with the forest as well, misleads him in betraying his wife, who is thus forced to leave her husband and her family. The forest, in other words, represents her own nature, the wild, chaotic existence outside of the human dimension. As soon as she can carve out a piece of land by means of Reymund's help, she is capable of establishing herself in that wilderness and create a new territory for herself and her children. But the same forces that she tries to control, represented by the forest, ultimately turn against her and destroy her by making her husband reveal her true nature.

The prose novel concludes with numerous accounts of the struggles by Melusine's sons against various monsters, but the forest itself then no longer matters as crucially as it does at the beginning when Reymund encountered the mysterious woman and her two sisters. Nevertheless, as we can realize, that was the very moment when his life took a decisive turn, allowing him to establish a new life and a dynasty on his own.

\section{The Forest in Fortunatus}

A final example can confirm how much the forest served as the staging ground for critical events in the lives of literary protagonists. In the anonymous novel Fortunatus (1509), which might have been composed sometime around 1450 or slightly later (Müller, 1990, pp. 1165-1167; Kästner, 1990, pp. 282-292), ${ }^{20}$ the protagonist twice acquires magical objects, the first, a purse that is never empty, and the second, a cap that allows the bearer to travel wherever he fancies to go. Unfortunately, as Fortunatus realizes only too quickly, his endless wealth creates much envy and suspicion, and he has a hard time to cope in this life without being threatened or even killed because of his money. Nevertheless, at the end he can realize his dream, marry the daughter of an impoverished count, and establish his own dynasty in Cyprus - and this in parallel to the situation in Melusine. But already the next generation, his two sons, fails in every regard, although they have their father's valuable objects available, the one because his ambitions take him too far afield, the other, because he is too content with his wealth and does not accept any challenge. The first is tortured to death by his enemies, and the other one dies out of grief over the loss of his brother.

The critical moment is reached in the first part when Fortunatus, having barely escaped a death penalty in London despite his complete innocence, encounters a magical figure, Lady Fortune, in the middle of the forest. Fortunatus runs into her only after he has lost his way, fears for his life because of wild beasts, especially a bear, and has reached a low point in his existence, being close to starvation. At that moment he is now offered the choice among: wisdom, wealth, strength, health, beauty, and a long life (Müller, 1990, p. 430). He does not reflect for long on the options, and selects wealth, which then becomes the decisive factor for the entire rest of the novel. Even though Fortunatus understands how to utilize his infinite resources quite skillfully and fittingly, traveling all over the known world, marrying a count's daughter, and establishing a good family, his two sons miserably fail in following his advice, and thus quickly come to a horrible end, each in his own way.

The narrator unmistakably conveys his message at the closure in a straightforward epimythion, emphasizing ${ }^{20}$ Kästner (1990), who suggests, with fairly good arguments, that the Nuremberg Franciscan and preacher Stephan Fridolin might
have composed this novel. 
that only the selection of wisdom would have been the correct one for Fortunatus. It would have been only reasonable to do so, as he underscores, since also King Solomon had followed that advice and thus had gained enormous wealth, after all (Müller, 1990, p. 580), However, as the narrator also alerts us in the final lines, such a Lady Fortune no longer exists because she has been chased away. In other words, every individual has to make that decision him/herself as to how to lead one's life by what criteria and with what goals in mind.

Lady Fortune, however, had told him that the fact that he had gotten lost in the forest was actually to his fortune. Nevertheless, she also had urged him to follow her advice to lead a virtuous life by means of his new wealth, which meaning that he should always celebrate the day when he had received his magical money bag, should abstain from carnal knowledge with a woman, and should help the daughter of an impoverished father to marry a man, providing her with a rich dowry (Müller, 1990, p. 431). Moreover, she had helped Fortunatus to find his way out of the forest, but he was not allowed to look back and see where she might disappear to. We clearly recognize here that the Orpheus-motif, ${ }^{21}$ except that Fortunatus closely observes her order, does not gaze backwards, and thus succeeds in leaving the forest, not at all a refuge for him from many external threats. He would have nearly starved to death, or he could have been eaten by a bear, but Fortunatus is lucky at the end, and then finally encounters the magical Lady Fortune.

Altogether, the forest proves to be the decisive turning point for the protagonist, since before the forest scene he was struggling hard to make a living as a servant and had to face injustice, jealousy, and hatred. Now, with the money purse all his material needs have disappeared, and he can enjoy his life as an independently wealthy individual. However, as the further developments illustrate, money does not make it easier or safer for him, since his wealth attracts others who would like to rob it from him and who would unhesitatingly kill him if they had the opportunity.

The forest serves as the ultimate testing ground for the protagonist, and the author utilized that wild space as the location where magic can occur. But the overall purpose of this prose novel consists of reflecting on the precariousness of human existence which the forest illustrates most dramatically. If we turned out attention to the large corpus of courtly romances dealing with the Tristan theme from the 12th through the 15th century, we would find much confirmation for this observation (Robinson Kelly, 2009, pp. 237-247). ${ }^{22}$ But there are many other examples of a forest in medieval literature characterized by its strong symbolic meaning, as we have seen already at the beginning.

\section{Conclusions}

This now allows us to conclude with some comments as to how the study of the forest as a concrete space and as a metaphor can make it possible to develop new teaching strategies for Medieval Studies (and by the same token for other periods in the Humanities). There are many reasons and purposes of teaching literary history at the university. While we traditionally regard literature classes as important for students to develop cultural awareness and aesthetic sensitivities in a historical context, and while we commonly rely on literature to educate our

\footnotetext{
${ }^{21}$ Research on Fortunatus does not yet seem to have recognized those parallels.

22 Curiously, for some poets, such as Béroul and Eilhart of Oberg, the Morois forest constitutes a miserable exile for the lovers, while Gottfried of Straßburg depicts the lovers' cave in the forest as a utopian space. In any case, both here and there the retreat into the forest serves as the critical catalyst leading the respective romances to their tragic outcomes. As Robinson observes (p. 237): “In banishment, the alienated placelessness of their love receives external, spatial expression”.
} 
students to train their analytic and writing skills by way of investigating literary texts, the treatment of the forest as a motif can also facilitate another approach to teaching. One of the strongest motivational factors in education has always been "curiosity”. The forest, significantly, represents the dark space beyond human civilization, either as a refuge or as a threat, or simply as the unknown territory.

Things happen in the forest that would not happen outside of it. The world of fairy tales is filled with accounts about animals or figures in the forest, or about events that take place in the forest. Similarly, medieval (and early modern) literature, above all, reveals a strong interest in the forest because there the protagonists' characters are challenged and tested, or where tragedy strikes them, or where their lives take a decisive turn. Sometimes we hear of individuals who take flight to the forest out of desperation about the tragic development in their lives, such as Bertschi Triefnas in Heinrich Wittenwiler's didactic-allegorical romance The Ring (ca. 1400) (Wittenwiler, 2012, vv. 9692-9696). Whatever happens in the forest, however, it regularly emerges as an epistemological challenge. Both the protagonists and the modern readers face the difficult task to figure out the meaning of the dark space of the wood, and sometimes it is presented in positive, optimistic terms, sometimes as the dead-end of a life. When the hero enters the forest, she might realize a happy turn of events, or the forest turns into the uncanny space which anticipates his or her death, such as in the anonymous heroic Middle High German epic, Nibelungenlied (ca. 1200) (Nibelungenlied, 2010, stanzas 913-998).

While the modern attitude toward the forest and our understanding of the true nature of the forest have certainly changed since the Middle Ages, ${ }^{23}$ especially because its survival is threatened today by environmental pollution and economic interests in wood as a commodity, its symbolic relevance and intrigue have not disappeared. While the modern battle cries pertain mostly to the preservation of this green space as the lungs of our world, the emotional attachment to or respect for the forest as the location of myth and history, of alterity and power continues to matter greatly. Studying medieval literature in that light will allow us to establish meaningful connections between past and present, hopefully placing the Middle Ages once again more toward the center of the Humanities. Based on anecdotal evidence, the general, public interest in that past world certainly exists, while school and college curricula are limping behind (Miedema \& Sieber, 2013). If we could remind future readers of medieval literature how much it consists of epistemological riddles and existential challenges, as expressed by the motif of the forest, for instance, we might be able to remove one of the most difficult barriers in teaching premodern texts again because modern readers will realize once again how much meaning and fun is contained in studying those medieval texts. The young generation all over the world, deeply thrilled by the Harry Potter novels, has already confirmed what the truly successful strategy consists of in giving relevance to a certain text. The theme of the forest in medieval literature invites our students to go on a quest on their own and to figure out what might be hidden in that dark, green space, waiting both for the literary protagonist and for themselves as readers. The forest is simply ominous, both then and today, and responds directly to human needs and inquiry.

\section{References}

Aberth, J. (2012). An environmental history of the Middle Ages: The crucible of nature. London and New York: Routledge. Adam, W. (1988). Poetische und kritische Wälder: Untersuchungen zu Geschichte und Formen des Schreibens "bei Gelegenheit" (Poetic and critical forests: Studies on the history and form of occasional writings). Heidelberg: Winter.

${ }^{23}$ Again, for a good survey, with a focus on the fairy tale, see Fischer (2011). 
Angeli, G. (2006). “Le ambiguità dell” “idillio” nei primi racconti francesi da Piramus et Tisbé a Aucassin et Nicolette (The ambiguity of the "idyllic" from the first accounts of Piramus and Thisbé to Aucassin and Nicolette). Rivista di Letterature Moderne e Comparate, 59(2), 137-150.

Augustine. (1960). The confessions of St. Augustine. (J. K. Ryan, Trans.). New York: Doubleday.

Augustine. (1992). Confessions (vol. I: Introduction and Text). J. J. O’Donnell, (Ed.). Oxford: Clarendon Press.

Bildhauer, B. (2006). Medieval blood. Religion and culture in the Middle Ages. Cardiff: University of Wales Press.

Brewer, D., \& Gibson, J. (Eds.). (1997). A companion to the Gawain-poet. Woodbridge, Suffolk, UK, and Rochester, NY: D. S. Brewer.

Bumke, J. (2001). Die Blutstrophen im Schnee: Über Wahrnehmung und Erkenntnis im "Parzival” Wolframs von Eschenbach (The drops of blood in the snow: On perception and understanding in Wolfram von Eschenbach's "Parzival”). Tübingen: Max Niemeyer.

Chazelle, C., Doubleday, S., Lifshitz, F., \& Remensnyder, A. G. (Eds.). (2012). Why the Middle Ages matter: Medieval light on modern injustice. London and New York: Routledge.

Classen, A. (1990). Utopie und logos (Utopia and logos). Heidelberg: Carl Winter Universitätsverlag.

Classen, A. (1995). The German Volksbuch: A critical history of a late-medieval genre. Lewiston, NY, Queenston, and Lampeter: Edwin Mellen Press.

Classen, A. (2000). Die Suche nach der Utopie in der Gralswelt. Albrechts (von Scharfenberg) Der jüngere Titurel (The search for utopia in Albrecht (von Scharfenberg)'s The younger Titurel). In B. R. Fernández (Ed.), Parzival. Reescritura y Transformación (pp. 133-156). Valencia: Universitat de València.

Classen, A. (2012). The role of the humanities past and present: Future perspectives based on ancient ideas: Reflections by a medievalist. Alfinge: Revista de Filología, 24, 9-30.

Classen, A. (Ed.). (2012). Rural space in the Middle Ages and Early Modern Age: The spatial turn in premodern studies. Berlin and Boston: Walter de Gruyter.

Cornelius, R. (2010). Vom Todesstreifen zur Lebenslinie: Wartburg-Werra-Rhön: Mensch und Natur am Grünen Band Deutschlands (From the death strip to the life line: Wartburg-Werra-Rhön: Humans and nature at the Green Band in Germany). Niederaula: Auwel-Verlag.

Dallapiazza, M. (2009). Wolfram von Eschenbach: Parzival. Berlin: Erich Schmidt Verlag.

Dante Alighieri. (1974). The divine comedy (Vol. 1: Inferno). (M. Musa, Trans.). London: Penguin.

Doob, P. (1990). The idea of the labyrinth from classical antiquity through the Middle Ages. Ithaca, NY, and London: Cornell University Press.

Drittenbass, C., \& Schnyder, A. (Eds.). (2010). Eulenspiegel trifft Melusine: Der frühneuhochdeutsche Prosaroman im Licht neuer Forschungen und Methoden. Akten der Lausanner Tagung vom 2. bis 4. Oktober 2008 (Eulenspiegel meets Melusine: The early new high German prose novel in light of new research and methods: Proceedings of the Lausanne meeting October 2 to 4, 2008). Amsterdam and New York: Editions Rodopi.

Dufournet, J. (Ed.). (1984). Aucassin et Nicolette (Aucassin and Nicolette). Paris: Garnier-Flammarion.

Eco, U. (1994). Six walks in the fictional woods (Charles Eliot Norton lectures, 1993). Cambridge, MA: Harvard University Press.

Elliott, R. W. V. (1979). Woods and forests in the Gawain country. Neuphilologische Mitteilungen, 80, 48-64.

Fischer, H. (2011). Wald. In R. W. Brednich, (Ed.), Enzyklopädie des Märchens (Encyclopedia of the fairy tale) (pp. 434-443). Berlin and Boston: Walter de Gruyter.

Frobel, K., Geidezis, L., \& Kreutz, M. (2011). Erlebnis Grünes Band (Experience of the green band). Bonn-Bad Godesberg: Bundesamt für Naturschutz.

Fuhrmann, H. (1996). Überall ist Mittelalter: Von der Gegenwart einer vergangenen Zeit (The Middle Ages are everywhere: From the presence of a past era). Munich: C. H. Beck.

Gadebusch Bondio, M. (Ed.). (2005). Blood in history and blood histories. Florence: SISMEL, Edizioni del Galluzzo.

Gilbert, J. (1997). The practice of gender in Aucassin et Nicolette. Forum for Modern Language Studies, 33(3), 217-228.

Giono, J. (1954/1985). The man who planted trees. Chelsea, VT: Chelsea Green Publishing Company.

Gotzkowsky, B. (1991). "Volksbücher”: Prosaromane, Renaissancenovellen, Versdichtungen und Schwankbücher: Bibliographir der deutschen Drucke. Part I: Drucke des 15. und 16. Jahrhunderts ("Popular books": Prose novels, renaissance novellas, verse narratives, and jest narratives: Bibliography of the German prints: Part I: Prints of the 15th and 16th centuries). Baden-Baden: Verlag Valentin Koerner.

Hartmann, H. (2010). Utopias/Utopian thought. In A. Classen (Ed.), Handbook of medieval studies: Terms—Methods—Trends (pp. 1400-1408). Berlin and New York: Walter de Gruyter. 
Haug, W. (1980/1989). Erzählen vom Tode her (Talking from the perspective of death). Strukturen als Schlüssel zur Welt: Kleine Schriften zur Erzählliteratur des Mittelalters (Structures as the keys to the world: Short studies on the narrative literature of the Middle Ages) (pp. 541-553). Tübingen: Max Niemeyer.

Hiltner, K. (Ed.). (2013). Ecocriticism: The essential reader. New York and London: Routledge.

Kinoshita, S., \& McCracken, P. (2012). Marie de France: A critical companion. Woodbridge: D. S. Brewer.

Kipfer, S., Goone Wardena, K., Schmid, C., \& Milgrom, R. (Eds.). (2008). Space, difference, everyday life: Reading Henri Lefebvre. New York and London: Routledge.

Lefebvre, H. (1974/1991). The production of space. (D. Nicholson-Smith, Trans.). Malden, MA, and Oxford: Blackwell.

Lehmann, A. (Ed.). (1998). Der Wald—ein deutscher Mythos?: Perspektiven eines Kulturthemas (The forest—A German myth? Perspectives of a culture theme). Berlin: Reimer.

Lekan, T., \& Zeller, T. (Eds.) (2005). Germany’s nature: Cultural landscapes and environmental history. New Brunswick, NJ: Rutgers University Press.

Marie de France. (2010). The lays of Marie de France. (E. J. Gallagher, Trans.). Indianapolis and Cambridge: Hackett Publishing.

Miedema, N., \& Sieber, A. (Eds.). (2013). Zurück zum Mittelalter: Neue Perspektiven für den Deutschunterricht (Back to the Middle Ages: New perspectives for teaching German). Frankfurt A. M., Berlin, et al.: Peter Lang.

Müller, J.-D. (Ed.). (1990). Romane des 15. und 16. Jahrhunderts (Novels of the 15th and 16th centuries). Frankfurt a. M.: Deutscher Klassiker Verlag.

Perez, R. A. (2012). The forest as locus of transition and transformation in the epic romance Berte aus grans pies. In A. Classen (Ed.), Rural space in the Middle Ages: The spatial turn in premodern studies (pp. 433-450). Berlin and Boston: Walter de Gruyter.

Physiologus. (1979). (M. J. Curley, Trans.). Austin: University of Texas Press.

Robinson Kelly, M. (2009). The hero's place: Medieval literary traditions of space and belonging. Washington, DC: The Catholic University of America Press.

Rudd, G. (2007). Greenery: Ecocritical readings of late medieval English literature. Manchester medieval literature. Manchester and New York: Manchester University Press.

Sabine, O. (Ed.). (2009). Tiere und Fabelwesen im Mittelalter (Animals and fable creatures in the Middle Ages). Berlin and New York: Walter de Gruyter.

Sager, A. (2006). Minne von maeren: On Wolfram's “Titurel” (Courtly love resulting from verse narratives: On Wolfram's “Titurel”). Göttingen: V \& R unipress.

Saunders, C. J. (1993). The forest of medieval romance: Avernus, Broceliande, Arden. Cambridge: Cambridge University Press.

Scarborough, C. (2013). Inscribing the environment: Ecocritical approaches to medieval Spanish literature. Berlin and Boston: Walter de Gruyter.

Schulze, U. (Ed.). (2010). Nibelungenlied. (S. Grosse, Trans.). Stuttgart: Reclam.

Semmler, J. (Ed.). (1991). Der Wald in Mittelalter und Renaissance (The forest in the Middle Ages and the renaissance). Düsseldorf: Droste Verlag.

Tax, P. W. (2011). Tragische spiegelungen: Herrschaft und sukzession, rang und stand in Wolframs “Titurel” (Tragic reflections: Domination and succession, rank and station in Wolfram's "Titurel”). Zeitschrift für deutsches Altertum und deutsche Literatur, 140, 38-57.

Theis, J. S. (2009). Writing the forest in early Modern England: A sylvan pastoral Nation. Medieval \& renaissance literary studies. Pittsburgh, PA: Duquesne University Press.

Thomasset, C., \& James-Raoul, D. (Eds.). (2005). En quête d'utopies (In the search of utopias). Paris: Presses de l’Université Paris-Sorbonne.

Vantuono, W. (Ed.). (Trans.). (1991). Sir Gawain and the green knight (A dual language version). New York and London: Garland.

Walker Bynum, C. (2007). Wonderful blood: Theology and practice in late medieval northern Germany and beyond. Philadelphia: University of Pennsylvania Press,

Walther von der Vogelweide. (2013; orig. 1827). Leich, Lieder, Sangsprüchel (15th ed.) (Edition der Melodien von Horst Brunner). T. Bein, (Ed.). Berlin and Boston: Walter de Gruyter.

Whalen, L. E. (Ed.). (2011). A companion to Marie de France. Leiden and Boston: Brill.

Wilson, J. K. (2012). The German forest: Nature, identity, and the contestation of a national symbol, 1871-1914. Toronto: University of Toronto Press. 
Wittenwiler, H. (2012). Der Ring: Text-Übersetzung—Kommentar. Nach der Münchener Handschrift herausgegeben, übersetzt und erläutert von Werner Röcke unter Mitarbeit von Annika Goldenbaum. Mit einem Abdruck des Textes nach Edmund Wießner (The ring: Text-translation—commentary: Edited on the basis of the Munich manuscript, translated and explained by Werner Röcke together with Annika Goldenbaum. With a reprint of the text edited by Edmund Wießner). Berlin and Boston: Walter de Gruyter.

Wolfram von Eschenbach. (1988). Titurel and the songs. (M. E. Gibbs, \& S. M. Johnson, Trans.). New York and London: Garland.

Wolfram von Eschenbach. (1998). Parzival: Studienausgabe (Parzival: A critical editions for students). (P. Knecht, Trans.). Berlin and New York: Walter de Gruyter.

Wolfram von Eschenbach. (2003). Titurel. (H. Brackert, \& S. Fuchs-Jolie, Trans.). Berlin and New York: Walter de Gruyter.

Wyss, U. (1974). Selbstkritik des Erzählers: Ein Versuch über Wolframs Titurelfragment (Self criticism of the narrator: An attempt with Wolfram's Titurel fragments). Zeitschrift für deutsches Altertum und deutsche Literatur, 103, 249-289.

Zechner, J. (2006). "Ewiger Wald und ewiges Volk”: Die Ideologisierung des deutschen Waldes im Nationalsozialismus ("Eternal forest and eternal people”: The ideologization of the German forest by the National Socialists). Freising: Technische Universität München, Lehrstuhl für Landschaftsökologie.

Zink, M. (1996/1998). The enchantment of the Middle Ages. (J. M. Todd, Trans.). Baltimore and London: The Johns Hopkins University Press. 